\title{
ONLINE REPURCHASE INTENTION: EMPIRICAL STUDY ON THE HOUSEHOLD EQUIPMENT MARKET
}

\author{
G. VIDELAINE, L. SCARINGELLA \\ Rennes School of Business, France
}

\begin{abstract}
The explosion of e-commerce has enabled consumers to purchase goods online. We have developed a conceptual framework based on the technology acceptance model, the expectation-confirmation theory and the concept of information systems continuance. Our intent is to conduct an empirical study on consumers' online repurchase of household equipment, which has not been undertaken before. 218 respondents answered our survey on the intention of online repurchase of IKEA products. Structural equation modeling has been used for the analysis. Concerning the household equipment market, our findings indicate that past Internet shopping experience affects online customers' perceived ease of use, confirmation and satisfaction. The usability of a website affects trust, perceived enjoyment and usefulness. Customers' confirmation affects satisfaction, but not perceived usefulness. Intention to repurchase household equipment online is positively affected by perceived usefulness and satisfaction. Analysis of our data leads to the counter-intuitive finding that online repurchase intention is negatively affected by perceived enjoyment. Our study contributes to bring together several extant online repurchase intention models.
\end{abstract}

Keywords: Internet, e-commerce, repurchase, household equipment, online shopping, IKEA.

JEL: M31.

\section{INTRODUCTION}

E-commerce has significantly changed the way consumers buy their products and services and offers advantages over shopping in a physical store [Wen, Prybutok, Xu, 2011]. The Internet has become an important marketing channel and an integral part of companies' strategy [Bart et al., 2005]. The Internet plays a strategic role in today's digital economy and facilitates new initiatives [Korzaan, Rutner, 2013].

M. Korzaan and P. Rutner argue that e-commerce "is growing faster than almost all other industries" and enables companies to generate revenue rapidly [Korzaan, Rutner, 2013, p. 70]. The fast growth of competition encourages companies to develop differentiation and enhance customer loyalty. Searching for new customers is important, however,

Postal Address: Rennes School of Business, 2 Rue Robert d'Arbrissel, Rennes, 35065, France.

(C) G. Videlaine, L. Scaringella, 2019

https://doi.org/10.21638/spbu18.2019.409 
reinforcing customer loyalty is considered even more profitable, because the cost of retaining customers is lower than that of finding new ones [Wen, Prybutok, Xu, 2011]. A. Bhattacherjee argues that "acquiring new customers may cost as much as five times more than retaining existing ones" [Bhattacherjee, 2001, p. 352]. Understanding the factors that influence consumers' online repurchase intention, is central to our research.

Several extant papers [Oliver, 1980; Davis, 1989; Wen, Prybutok, Xu, 2011; Chen, 2012] contributed to the understanding of consumers' online purchase and repurchase behavior. The technology acceptance model (TAM) defined by F. Davis has explained consumers' intentions of using information technology [Davis, 1989]. The expectation-confirmation model (ECM) defined by Oliver was more focused on consumers' intentions of reusing the technology [Oliver, 1980]. Some more recent models have concentrated more specifically on online repurchase intention. Wen, Prybutok, Xu's model defined in 2011 reused the TAM and the ECM to validate the hypotheses concerning online repurchase intention [Wen, Prybutok, Xu, 2011]. Chen's model defined in 2012 also used the TAM and the ECM, as well as two other extant theories: the social cognitive theory and the social learning theory, which help to conceptualize the antecedents that influence consumers' online repurchase intentions [Chen, 2012].

Some studies have already been carried out in specific sectors to understand consumers' decision to repurchase online. Among those sectors are apparel websites [Tong, 2010; Lee, Hodges, 2012], tourism websites [Kim et al., 2014], the B2C market [Zhang et al., 2011] and luxury products [Ciornea, 2013]. However, no studies have been conducted on the household equipment market. The household equipment market comprises the following products: furniture, household electrical goods, home textile, decoration, lights and tableware. The leaders on the online household equipment market are: BUT, IKEA, Conforama, Darty, Boulanger, Desforges, Zara Home.
Our study addresses the following research question: what are the factors that influence consumers in their decision to repurchase household equipment online?

In the past years, different studies have been conducted about consumers' online purchase and repurchase behavior. However, we observe that the current literature remains very separated in the sense that previous works [Oliver, 1980; Davis, 1989; Wen, Prybutok, Xu, 2011; Chen, 2012] remain very disconnected from each other, while we would learn more by having an integrated framework that embrace the existing studies. Our intended contribution is to bring together four streams of research [Oliver, 1980; Davis, 1989; Wen, Prybutok, Xu, 2011; Chen, 2012], which was missing in the existing literature. Consequently, our contribution is bringing convergence to the existing studies. We also aim at filling an empirical research gap by studying the specific case of the household equipment market to complement the existing studies dealing with apparel websites, tourism websites, the B2C market and luxury products.

In the remainer of this paper, we provide a critical review of existing models and theories (TAM, ECM, Wen, Prybutok, Xu's model and Chen's model). Then, based on existing theories, we develop our hypotheses and the analytical framework for studying the household equipment market. After that, we present the methodology we have used in our empirical study. After performing the analysis using structural equation modeling, based on our empirical results, we provide the results discussion and their contriubtion to the literature.

\section{LITERATURE REVIEW}

In this literature review, we examine more specifically four models. We have considered both the TAM and ECM models as the theoretical basis for our study as well as the Wen, Prybutok, Xu's and Chen's models that are more relevant for our research aim. 
Hypothesis tested in the expectation-confirmation model

\begin{tabular}{l|c}
\hline \multicolumn{1}{c|}{ Hypothesis } & Result \\
\hline H1. Users' level of satisfaction with initial information systems use is positively associated & Supported \\
with their information systems continuance intention. & Supported \\
H2. Users' extent of confirmation is positively associated with their satisfaction with infor- \\
mation systems use.
\end{tabular}

\subsection{The Technology Acceptance Model}

The purpose of the TAM developed by Davis and co-authors is to explain consumers' behavioral intention to use a system [Davis, 1989; Davis, Bagozzi, Warshaw, 1989]. The authors argued that the usefulness and user-friendliness of a technology positively influence a consumer's decision to use it again. Similar findings have been reported in the specific case of online purchase [Wen, Prybutok, Xu, 2011; Chen, 2012]. Widely acknowledged in this field of study, this model focuses on factors such as perceived usefulness and perceived user-friendliness and consequently does not take into account other possible determinants of behavioral intention to use a technology, such as trust or satisfaction. The models look at consumers' intention to use a technology or their initial decision to purchase it and neither addresses the question of reuse, nor that of repurchase. This is why we decided to use Bhattacherjee's ECM [Bhattacherjee, 2001] in conjunction with the TAM.

\subsection{The Expectation-Confirmation Model and the Information Systems Continuance}

In the information systems (IS) continuance model, A. Bhattacherjee argues that consumers' satisfaction is a function of expectation, perceived performance and confirmation, which encourages consumers to repeat online purchases [Bhattacherjee, 2001]. This model was based on the ECM [Oliver, 1980], which evaluates consumers' satisfaction, post-purchase behavior and the marketing service in general. With the revised information systems continuance model, A. Bhattacherjee argues that consumers' information systems continuance intention is primarily determined by satisfaction and perceived usefulness [Bhattacherjee, 2001]. User satisfaction is determined by perceived usefulness and confirmation (expectations confirmed), and perceived usefulness is influenced by users' confirmation. However, this model does not take into account other important factors such as trust, perceived ease of use and perceived enjoyment. In the Table 1 , we are providing the summaries of the hypothesizes tested in the ECM.

\subsection{Wen, Prybutok, Xu's Model}

Based on [Davis, 1989] and [Bhattacherjee, 2001], Wen, Prybutok and Xu developed a specific model for e-commerce [Wen, Prybutok, $\mathrm{Xu}, 2011]$. This model is one of the best suited for understanding the motives behind customers' decision to return and repurchase goods from a household equipment website because it takes into account almost all the constructs we need to evaluate and test in our study. The authors validated Davis' and Bhattacherjee's hypotheses [Davis, 1989; Bhattacherjee, 2001]. 
Hypothesis tested in the Wen, Prybutok, Xu's model

\begin{tabular}{l|l}
\hline \multicolumn{1}{c|}{ Hypothesis } & \multicolumn{1}{c}{ Result } \\
\hline H1: A customer's perceived ease of use of an e-commercial website positively affects a & Supported \\
customer's perceived usefulness. & \\
H2: A customer's perceived usefulness of an e-commercial website positively affects a cus- & Supported \\
$\quad$ tomer's online repurchase intention. & \\
H3: A customer's confirmation of an e-commercial website positively affects a customer's & Supported \\
perceived usefulness. & \\
H4: A customer's confirmation of an e-commercial website positively affects a customer's & Supported \\
$\quad$ online shopping satisfaction. & \\
H5: A customer's perceived usefulness of an e-commercial website positively affects a cus- & Supported \\
$\quad$ tomer's online shopping satisfaction. & \\
H6: A customer's shopping satisfaction at an e-commercial website positively affects a & Supported \\
$\quad$ customer's online repurchase intention. & \\
H7: A customer's perceived ease of use of an e-commercial website positively affects a \\
$\quad$ customer's trust.
\end{tabular}

There is a positive relationship between perceived ease of use and perceived usefulness, between confirmation and perceived usefulness, between confirmation and satisfaction and between perceived usefulness and satisfaction. The authors have also tested hypotheses concerning the relationships between perceived usefulness and trust, between trust and perceived usefulness, between perceived usefulness and online repurchase intention, between satisfaction and online repurchase intention and between perceived enjoyment and online repurchase intention. The only hypothesis which was not validated was that of the relationship between trust and online repurchase intention. Previous internet shopping experience is not included in this model although it might have a direct impact on customers' intention to repurchase online. This latter point was explained in Chen's model. In the Table 2 we provide summary of the hypotheses tested in the Wen, Prybutok, Xu's model [Wen, Prybutok, Xu, 2011].

\subsection{Chen's Model}

Similarly to [Wen, Prybutok, Xu, 2011], Y.-Y. Chen revisited the TAM and ECM models [Chen, 2012]. Chen extended the theoretical framework by considering social cognitive theory and social learning theory [Chen, 2012]. The social congnitive theory posits that learning occurs through the reciprocal interaction of the person, environment and behavior. The theory also states that self-confidence, controllability, motivation to succeed have an impact on individuals' cognition [Bandura, 1986]. The social learning theory posits that learning is a cognitive process that must be considered in its social context because individuals learn through observation of others. Learning has a mimetic dimension [Ormrod, 1999]. In the Table 3, we are providing the summaries of the hypothesizes tested in the Y.-Y.Chen's model [Chen, 2012].

The above discussed four models are summarized in the Table 4. 
Hypothesis tested in the Chen's model

\begin{tabular}{l|l}
\hline \multicolumn{1}{c|}{ Hypothesis } & \multicolumn{1}{c}{ Result } \\
\hline $\begin{array}{l}\text { H1a: Positive Internet shopping experience has a positive impact on Internet shopping } \\
\text { self-efficacy. }\end{array}$ & Supported \\
$\begin{array}{l}\text { H1b: Positive Internet shopping experience has an Internet shopping experience has a } \\
\text { positive impact on perceived usefulness. }\end{array}$ & Supported \\
H1c: Positive Internet shopping experience has a positive impact on confirmation. & Supported \\
H1d: Positive Internet shopping experience has a positive impact on satisfaction. & Supported \\
H2a: Behavior modeling has a positive impact on Internet shopping self-efficacy. & Not supported \\
H2b: Behavior Modeling has a positive impact on perceived usefulness. & Supported \\
H2c: Behavior Modeling has a positive impact on confirmation. & Supported \\
H3a: Internet shopping self-efficacy has a positive impact on perceived usefulness. & Supported \\
H3b: Internet shopping self-efficacy has a positive impact on confirmation. & Not supported \\
H3c: Internet shopping self-efficacy has a positive impact on repurchase intention. & Supported \\
H4a: Confirmation has a positive impact on satisfaction. & Supported \\
H4b: Confirmation has a positive impact on perceived usefulness. & Supported \\
H4c: Confirmation has a positive impact on perceived ease of use. & Supported \\
H5a: Perceived usefulness has a positive impact on satisfaction. & Supported \\
H5b: Perceived usefulness has a positive impact on repurchase intention. & Supported \\
H6a: Perceived ease of use has a positive impact on perceived usefulness. & Supported \\
H6b: Perceived ease of use has a positive impact on satisfaction. & Supported \\
H6c: Perceived ease of use has a positive impact on repurchase intention. & Supported \\
H7: Satisfaction has a positive impact on repurchase intention. & Supported \\
\hline
\end{tabular}

Table 4

Comparison of the frameworks

\begin{tabular}{|c|c|c|c|c|}
\hline & $\begin{array}{c}\text { TAM } \\
\text { [Davis, 1989] }\end{array}$ & $\begin{array}{c}\text { ECM } \\
\text { [Bhattacherjee, 2001] }\end{array}$ & $\begin{array}{c}\text { Wen, Prybutok, Xu's } \\
\text { model [Wen, Prybutok, } \\
\text { Xu, 2011] }\end{array}$ & $\begin{array}{l}\text { Chen's model } \\
\text { [Chen, 2012] }\end{array}$ \\
\hline 1 & 2 & 3 & 4 & 5 \\
\hline$\overline{\mathrm{Aim}}$ & $\begin{array}{l}\text { Consumer's behavior- } \\
\text { al intention } \\
\end{array}$ & Post-adoption intention & $\begin{array}{l}\text { Online repurchase in- } \\
\text { tention }\end{array}$ & $\begin{array}{l}\text { Online repurchase } \\
\text { intention }\end{array}$ \\
\hline $\begin{array}{l}\text { Research } \\
\text { question }\end{array}$ & $\begin{array}{l}\text { What causes peo- } \\
\text { ple to accept or reject } \\
\text { information techno- } \\
\text { logy? }\end{array}$ & $\begin{array}{l}\text { What are the salient } \\
\text { motivations underlying IS } \\
\text { users' intention to con- } \\
\text { tinue using an IS after } \\
\text { its initial acceptance? } \\
\text { How do these motiva- } \\
\text { tions influence continu- } \\
\text { ance intention? }\end{array}$ & $\begin{array}{l}\quad \text { How to explain cus- } \\
\text { tomer continued use } \\
\text { of an e-commerce web- } \\
\text { site in an integrated } \\
\text { model? }\end{array}$ & $\begin{array}{l}\text { Why do consum- } \\
\text { ers go Internet } \\
\text { shopping again? } \\
\quad \text { Understanding } \\
\text { the antecedents of } \\
\text { repurchase inten- } \\
\text { tion }\end{array}$ \\
\hline $\begin{array}{l}\text { Research } \\
\text { design }\end{array}$ & Quantitative & Quantitative & Quantitative & Quantitative \\
\hline Data & $\begin{array}{l}2 \text { studies: } \\
\text { 1) Field study with } \\
\text { a sample of } 120 \\
\text { users in Canada; } \\
\text { 2) Lab study with } \\
40 \text { participants } \\
\text { from MBA Stu- } \\
\text { dents in Boston }\end{array}$ & $\begin{array}{l}\text { Cross-sectional field } \\
\text { survey of online banking } \\
\text { users; } 1000 \text { online cus- } \\
\text { tomers selected from } \\
\text { a customer base of } 1 \mathrm{mln} \\
\text { users }\end{array}$ & $\begin{array}{l}\text { Paper-based ques- } \\
\text { tionnaire; } 230 \text { college } \\
\text { students in US }\end{array}$ & \begin{tabular}{l}
\multicolumn{1}{c}{ Questionnaire; } \\
463 respondents, \\
who have already \\
had an online shop- \\
ping experience \\
from the online \\
virtual store of \\
7-Eleven in Taiwan
\end{tabular} \\
\hline
\end{tabular}


Table 4 (end)

\begin{tabular}{c|l|l|l|l}
\hline $\mathbf{1}$ & $\mathbf{2}$ & \multicolumn{1}{c|}{$\mathbf{3}$} & \multicolumn{1}{c}{$\mathbf{4}$} & \multicolumn{1}{c}{$\mathbf{5}$} \\
\hline Findings & $\begin{array}{l}\text { Relationship between } \\
\text { perceived ease of use } \\
\text { and perceived useful- } \\
\text { ness }\end{array}$ & $\begin{array}{l}\text { Importance of satisfac- } \\
\text { tion with IS use having } \\
\text { an impact on users' con- } \\
\text { tinuance intention. } \\
\text { Perceived usefulness } \\
\text { predicting acceptance in- } \\
\text { tention }\end{array}$ & $\begin{array}{l}\text { Consumers' intention } \\
\text { to repurchase online. } \\
\text { Impact of marketing } \\
\text { and social psychology. } \\
\text { Confirmation of } \\
\text { TAM model adapted to } \\
\text { IT continuance usage }\end{array}$ & $\begin{array}{l}\text { Consumers re- } \\
\text { purse intention. } \\
\text { Consistent with } \\
\text { existing TAM and } \\
\text { ECM }\end{array}$ \\
\hline
\end{tabular}

\section{HYPOTHESES DEVELOPMENT}

Studied by [Radner, Rothschild, 1975; Karhanna, Straub, Chervany, 1999], perceived ease of use is defined as "the extent to which a consumer perceives the ease of interaction with the e-commerce website and is able to receive the product information that he or she needs" [Wen, Prybutok, Xu, 2011, p. 15]. An easy-to-use website will encourage consumers to revisit it. A website is considered user-friendly when users can easily find the information they need, when it is easy to navigate and is visually attractive [Rice, 1997]. Inversely, if customers have difficulties finding and ordering a product on a website compared to competitors' websites, the website is considered to be difficult to use [Chen, 2012]. According to [Chen, 2012], prior Internet shopping experience increases the probability of users' expectations to be confirmed and satisfied. And past experience also generates future expectations.

H1. Positive Internet shopping experience has a positive impact on the perceived ease of use of household equipment websites.

Confirmation was defined by A. Bhattacherjee as a cognitive belief representing the extent to which consumers' ex-ante expectations of service use were met in reality and refers to this evaluation process [Bhattacherjee, 2001]. Prior online shopping experience has a strong impact on the users' future online shopping behavior [Chen, 2012]. A positive perceived experience has a positive effect on users confirmation, because it is a factor in satisfying current expectations and in creating future ones [Chen, 2012]. Users whose initial expectations were met are more likely to expect positive perceived usefulness and confirmation in future.

H2. Positive Internet shopping experience

has a positive effect on confirmation in household equipment online stores.

Perceived usefulness was defined as "the degree to which a person believes that using a particular system would enhance his or her job performance" [Davis, 1989, p. 320]. Other similar definitions were given by [Karahanna, Straub, Chervany, 1999]. In the TAM model presented by Davis and in [Chau, 2001], it is argued that perceived usefulness has a direct and significant effect on behavior intentions. Chen finds that past internet shopping experiences has an impact on perceived usefulness [Chen, 2012]. A website is perceived as useful if it is useful, effective, helpful, functional, necessary and practical [Zumpe, Van der Heijden, 2007].

H3. Positive Internet shopping experience is positively related to perceived usefulness in household equipment online shopping.

The first definition of satisfaction was given by [Locke, 1976, p. 1300] as "a pleasurable or positive emotional state resulting from the appraisal of one's job". The concept was then understood more broadly as "the summary psychological state resulting when the emotion surrounding disconfirmed expectations is coupled with the consumer's prior feelings about the consumption experience" [Oliver, 1981, p. 29]. Woodruff, Cadotte and Jenkins argue that if a consumer's per- 
ception of a product or a service is positive, his/her satisfaction in the product and in the overall service will be higher [Woodruff, Cadotte, Jenkins, 1983]. Shankar, Smith and Rangaswamy pointed out that users with the highest level of satisfaction are those that have had satisfying online shopping experience [Shankar, Smith, Rangaswamy, 2003].

When they have positive experiences in online shopping, individuals become more proficient and less intimidated by the process, which considerably improves their satisfaction [Chen, 2012].

$\mathrm{H} 4$. Positive Internet shopping experiences have a positive effect on satisfaction in household equipment websites.

D. Kim, D. Ferrin and H. Rao understand trust as "a multidimensional concept related to various targets: sales person, product, company and Internet trust". They define online consumer trust as "the consumer's subjective belief that the selling party or entity on the Internet will fulfill its transactional obligations as the consumer understands them" [Kim, Ferrin, Rao, 2008, p. 554]. Definitions of trust have been given by various scholars (e.g. [Gefen, Karahanna, Straub, 2003; Kim, Ferrin, Rao, 2008; Zhu, Lee, O’Neal, 2011]). They argue that trust is more important in the e-commerce environment than in traditional commerce because of the distance and other personal factors [Wen, Prybutok, Xu, 2011]. Privacy and security practices, website design - particularly navigation and presentation - brand strength and order fulfillment are all antecedents of online trust because consumers wish to protect the confidentiality of their data and want their expectations to be met [Bart et al., 2005]. Consumers have more trust in websites they have previously used for shopping [Bart et al., 2005] and when an online vendor is available [Wen, Prybutok, Xu, 2011]. D. Gefen and D.Straub integrated the construct of trust within the TAM framework and explained that trust influenced usage intention directly and indirectly via the perceived ease of use [Gefen, Straub, 2003].
H5. Positive perceived ease of use positively influences trust in household equipment websites.

As already mentioned, the perceived ease of use of a website encourages users to revisit it [Rice, 1997]. The online shopping is not only means of acquiring goods or services but it can also provide enjoyment [Kim, Ammeter, 2008]. If a website brings enjoyment to consumers through positive perceived ease of use, they will be more likely to return to that website and to make other purchases.

H6. Positive perceived ease of use is positively related to perceived enjoyment in household equipment websites.

According to TAM, perceived ease of use and perceived usefulness are considered as predictors of behavioral intentions [Davis, 1989]. Perceived ease of use is an antecedent of perceived usefulness [Davis, 1989; Gefen, Karahanna, Straub, 2003]. If users interact easily with a website, can easily find product information or pay online, they will consider their online shopping more useful [Wen, Prybutok, Xu, 2011].

H7. Positive perceived ease of use is positively related to perceived usefulness of household equipment websites.

In the ECM, A. Bhattacherjee pointed out that in the post-acceptance stage, the perceived usefulness was influenced by users' confirmation level [Bhattacherjee, 2001]. The author explained that post-purchase expectation can be enhanced if consumers see benefits in the product or service that they had not expected initially. On the contrary, perceived usefulness can decrease if users' expectations (confirmation) are not met. This argument has been presented by several authors [Wen, Prybutok, Xu, 2011; Bhattacherjeein, 2001; Liao, Palvia, Chen, 2009; Hong, Thong, Tam, 2006]. Chen explained that if consumers' expectations of their online experience are confirmed, their perception of the website will be enhanced [Chen, 2012].

H8. Confirmation of expectations is positively related to perceived usefulness of household equipment websites. 
A. Bhattacherjee notes that customers' pre-purchase expectation and a positive perceived performance of the product once they have received and used it will confirm their expectations of the product (confirmation) and will increase their satisfaction [Bhattacherjee, 2001]. Expectation and perceived performance are two antecedents of confirmation [Chen, 2012]. If customers are satisfied and if the product or service meet their expectations, they will be satisfied. H. Kuan, G. Bock and V. Vatthanophas explained that perceived quality information, such as the website's content, accuracy, and format, positively influence users' satisfaction [Kuan, Bock, Vatthanophas, 2008]. If the performance of the product meets the customers' expectations, the latter will be confirmed and the customers' satisfaction will increase, which will influence them to visit the website again and to purchase products from it again. Bhattacherjee also argues that confirmation is an antecedent of customers' satisfaction [Bhattacherjee, 2001].

H9. Confirmation of expectations is positively related to satisfaction in household equipment websites.

Trust was defined as a predictor of perceived usefulness of a website because it helps enhance the users' shopping comfort [Zhu, Lee, O'Neal, 2011]. When e-vendors improve consumers' trust by meeting their expectations, consumers will then perceive the website as useful. According to [Gefen, Karahanna, Straub, 2003], trust positively influences perceived usefulness of a website.

H10. Trust in a household equipment website is positively related to its perceived usefulness.

Intention of continued purchase was defined as "the likelihood that an online customer will return to the website and purchase again in the future" [Davis, 1989]. As mentioned previously, trust in e-commerce is extremely important and influences consumers' intention to purchase online [Wen, Prybutok, Xu, 2011]. Gefen, Kara- hanna and Straub have argued that online customers are influenced by their trust in the e-vendor [Gefen, Karahanna, Straub, 2003]. Zhu, Lee and O'Neal find that trust in an online vendor has a significant impact on purchase intention by reducing the user's perceived risk of online shopping [Zhu, Lee, O'Neal, 2011]. Wen, Prybutok, Xu's study did not confirm the relationship between trust and online repurchase intention [Wen, Prybutok, $\mathrm{Xu}, 2011]$. Validation of the hypothesis requires further empirical studies in other industry contexts.

H11. Trust is positively related to intention of continued purchase from an online household equipment store.

As mentioned above the construct "perceived enjoyment" refers to the extent to which using an online store is enjoyable. Online shopping enjoyment, just as in-store shopping enjoyment, is important as it influences consumers' intention and behavior [Wen, Prybutok, Xu, 2011]. In the prepurchase phase, customers are curious and concerned about the ease of use of the website and privacy and security issues. Perceived ease of use and trust are the most important factors in their purchase decision. In the purchase phase, if customers enjoy their visit to the website, they are more likely to make the decision to purchase an item and to visit and purchase products again. In this respect, Wen, Prybutok and $\mathrm{Xu}$ argued that shopping enjoyment has a positive impact on users' intention to return [Wen, Prybutok, Xu, 2011].

H12. Perceived enjoyment is positively related to users' intention of repurchasing household equipment online.

When websites are perceived as useful, clients are more likely to be satisfied, and therefore to visit the online store again and make new purchases [Bhattacherjee, 2001; Hong, Thong, Tam, 2006; Liao, Palvia, Chen, 2009; Wen, Prybutok, Xu, 2011]. Several articles [Devaraj, Fan, Kohli, 2002; Chen, 2012] argued that perceived usefulness had an impact on satisfaction in the e-commerce context. 
H13. Perceived usefulness is positively related to satisfaction in household equipment websites.

We make a clear distinction between online purchase intention and online repurchase intention. The first refers to the initial purchase intention, which is related to customer conversion. The concept of customer conversion refers to the process through which a prospective online customer is converted into a buying customer [Kuan, Bock, Vatthanophas, 2008]. The second is the intention of continued purchase, which is also associated with customer retention. This refers to how an online store ensures that its existing customers remain its customers and continue purchasing from the store [Kuan, Bock, Vatthanophas, 2008]. Bhattacherjee's ECM [Bhattacherjee, 2001], as well as Chen's [Chen, 2012] and Wen, Prybutok, Xu's [Wen, Prybutok, Xu, 2011] models validate the hypothesis of a relation between perceived usefulness and online repurchase intention.

H14. Perceived usefulness is positively related to intention of repurchasing household equipment online.

The relationship between satisfaction and continued intention was examined in
Bhattacherjee's ECM [Bhattacherjee, 2001]. Wen, Prybutok and $\mathrm{Xu}$ define satisfaction as "the summary psychological state resulting when the emotion surrounding disconfirmed expectations is coupled with the consumer's prior feelings about the consumption experience" [Wen, Prybutok, Xu, 2011, p.16]. Similarly to [Bhattacherjee, 2001; Hong, Thong, Tam, 2006; Liao, Palvia, Chen, 2009; Wen, Prybutok, Xu, 2011], we anticipate that there is a positive relationship between satisfaction and information systems continuance usage intention.

H15. Satisfaction is positively related to users intention to purchase household equipment online again.

Based on classic theories and models such as the TAM [Davis, 1989], the information systems continuance and ECM [Oliver, 1980; Bhattacherjee, 2001] and more recent models developed by Chao Wen and co-authors [Wen, Prybutok, Xu, 2011] and Chen [Chen, 2012], we have formulated fifteen hypotheses summarized in Table 5. We have also developed the corresponding conceptual framework that incorporates all discussed constructs that influence online repurchase intention in the household equipment market (Fig. 1).

Table 5

Hypothesizes and the support from the literature

\begin{tabular}{|c|c|c|}
\hline Hypothesis & Implied relationship & Support by previous research \\
\hline 1 & 2 & 3 \\
\hline H1 & $\mathrm{PE} \rightarrow \mathrm{PEOU}$ & Never studied before \\
\hline $\mathrm{H} 2$ & $\mathrm{PE} \rightarrow \mathrm{CON}$ & [Chen, 2012] \\
\hline H3 & $\mathrm{PE} \rightarrow \mathrm{PU}$ & [Chen, 2012] \\
\hline $\mathrm{H} 4$ & $\mathrm{PE} \rightarrow \mathrm{SAT}$ & $\begin{array}{l}\text { [Woodruff, Cadotte, Jenkins, 1983]. } \\
\text { [Shankar, Smith, Rangaswamy, 2003]. } \\
\text { [Chen, 2012] }\end{array}$ \\
\hline H5 & $\mathrm{PEOU} \rightarrow \mathrm{TRU}$ & $\begin{array}{l}\text { [Gefen, Karahanna, Straub, 2003]. } \\
\text { [Wen, Prybutok, Xu, 2011] }\end{array}$ \\
\hline H6 & $\mathrm{PEOU} \rightarrow \mathrm{ENJ}$ & Never studied before \\
\hline $\mathrm{H} 7$ & $\mathrm{PEOU} \rightarrow \mathrm{PU}$ & $\begin{array}{l}\text { [Davis, Bagaozzi, Warshaw, 1989]. } \\
\text { [Gefen, Karahanna, Straub, 2003]. } \\
\text { [Wen, Prybutok, Xu, 2011]. [Chen, 2012] }\end{array}$ \\
\hline
\end{tabular}


Table 5 (end)

\begin{tabular}{c|c|l}
\hline $\mathbf{1}$ & $\mathbf{2}$ & \multicolumn{1}{c}{$\mathbf{1}$} \\
\hline H8 & CON $\rightarrow$ PU & $\begin{array}{l}\text { [Bhattacherjee, 2001]. [Wen, Prybutok, Xu, 2011]. } \\
\text { [Chen, 2012]. [Liao, Palvia, Chen, 2009]. } \\
\text { [Hong, Thong, Tam, 2006] }\end{array}$ \\
\hline H9 & CON $\rightarrow$ SAT & $\begin{array}{l}\text { [Bhattacherjee, 2001]. [Hong, Thong, Tam, 2006]. } \\
\text { [Wen, Prybutok, Xu, 2011]. [Chen, 2012] }\end{array}$ \\
\hline H10 & TRU $\rightarrow$ PU & $\begin{array}{l}\text { [Wen, Prybutok, Xu, 2011]. } \\
\text { [Zhu, Lee, O'Neal, 2011] }\end{array}$ \\
\hline H11 & TRU $\rightarrow$ INT & [Wen, Prybutok, Xu, 2011] \\
\hline H12 & ENJ $\rightarrow$ INT & [Chen, 2012] \\
\hline H13 & PU $\rightarrow$ SAT & $\begin{array}{l}{[\text { Bhattacherjee, 2001]. [Wen, Prybutok, Xu, 2011]. }} \\
\text { [Chen, 2012] }\end{array}$ \\
\hline H14 & PU $\rightarrow$ INT & $\begin{array}{l}{[\text { Bhattacherjee, 2001]. [Wen, Prybutok, Xu, 2011]. }} \\
\text { [Chen, 2012] }\end{array}$ \\
\hline H15 & SAT $\rightarrow$ INT & $\begin{array}{l}{[\text { Bhattacherjee, 2001]. [Hong, Thong, Tam, 2006]. }} \\
\text { [Wen, Prybutok, Xu, 2011]. [Chen, 2012] }\end{array}$ \\
\hline
\end{tabular}

N ot es: $P E O U$ - perceived ease of use; $C O N$ - confirmation; TRU - trust; $P U$ - perceived usefulness; $S A T$ - satisfaction; $E N J$ - perceived enjoyment; $P E$ - past internet shopping experiences; $I N T$ - online repurchase intention.

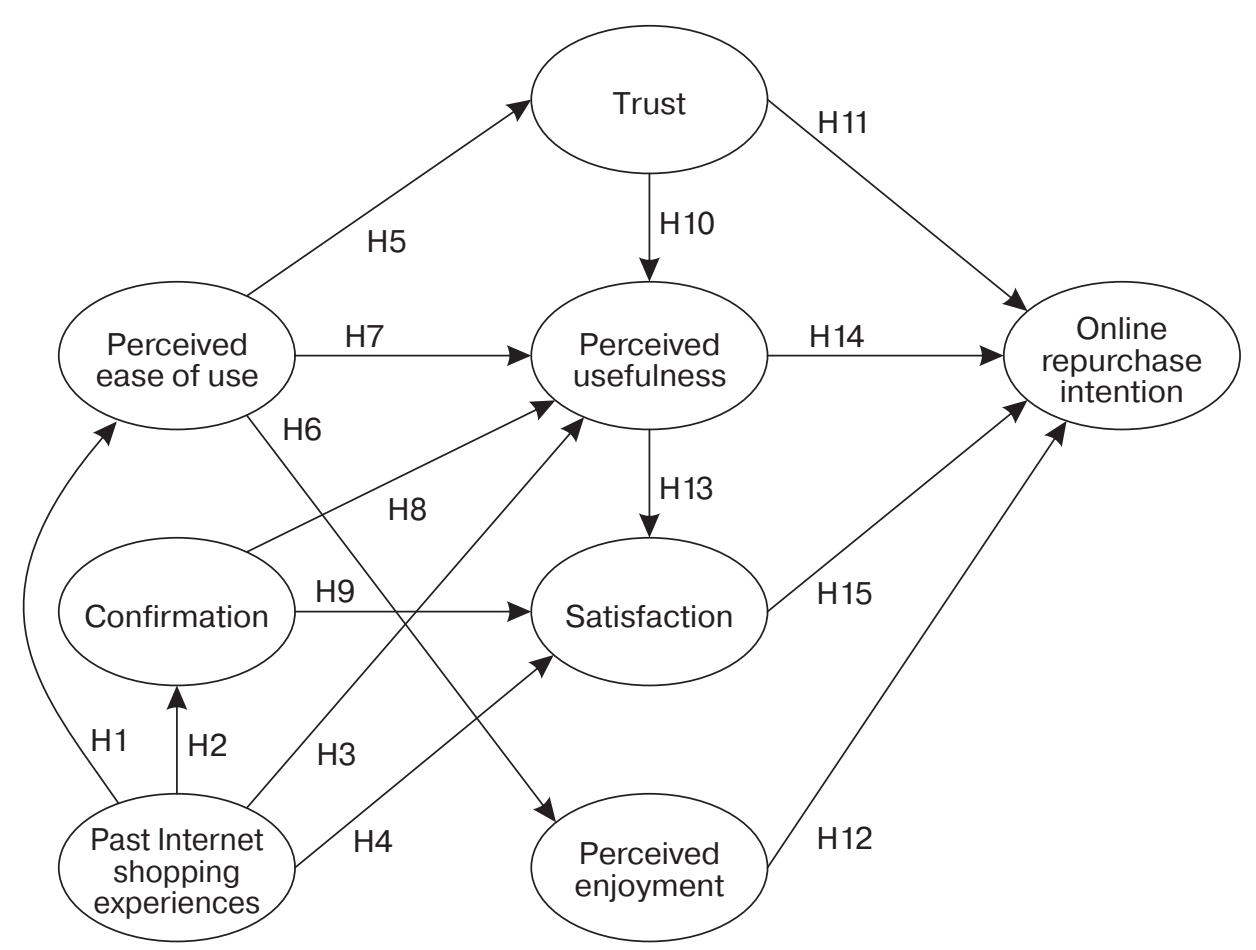

Fig. 1. Framework of repurchase intention in online household equipment stores 


\section{METHODOLOGY}

In order to simultaneously estimate several relationships, structural equation modeling is an appropriate technique for our analysis. It was previously used in other studies on the same subject (e.g. [Wen, Prybutok, Xu, 2011; Kim et al., 2012]).

\subsection{Individual Constructs}

We used the following reflective constructs: perceived ease of use (PEOU) [Davis, 1989; Gefen, Karahanna, Straub, 2003; Bigné-Alcañiz et al., 2008], confirmation (CON) [Hong, Thong, Tam, 2006], trust (TRU) [Gefen, Karahanna, Straub, 2003; Hassanein, Head, 2007], perceived usefulness (PU) [Davis, 1989; Bigné-Alcañiz et al., 2008], sat- isfaction (SAT) [Hong, Thong, Tam, 2006], perceived enjoyment (ENJ) [Van der Heijden, 2004; Hassanein, Head, 2007], past internet shopping experiences (PE) [Zeithaml, Parasuraman, Malhorta, 2002; Doll et al., 2004], online repurchase intention (INT) [Bhattacherjee, 2001; Devaraj, Fan, Kohli, 2002].

This study has used a perceptual measurement method based on the point of view of e-customers. In subjective performance indicators are highly correlated with objective performance indicators [Dess, Robinson, 1984]. We have chosen individuals' perception (i.e. opinions and feelings) as the unit of analysis. The data was collected from e-customers. Consequently, our study takes the individual as its unit of analysis.

The measurement scales used in our empirical studies are detailed in Table 6.

Table 6

Measurement scales of the constructs

\begin{tabular}{|c|c|}
\hline Construct & Item \\
\hline 1 & 2 \\
\hline $\begin{array}{l}\text { Perceived ease of use } \\
\text { (PEOU) [Davis, 1989; Gefen, } \\
\text { Karahanna, Straub, 2003; } \\
\text { Bigné-Alcañiz et al., 2008] }\end{array}$ & $\begin{array}{l}\text { The online shopping website is easy to use. } \\
\text { The online shopping website is flexible to interact with. } \\
\text { It is easier to use the Internet to find products that I want to buy }\end{array}$ \\
\hline $\begin{array}{l}\text { Confirmation (CON) } \\
\text { [Hong, Thong, Tam, 2006] }\end{array}$ & $\begin{array}{l}\text { The last experience with shopping online was better that I expected. } \\
\text { The service level provided by the website was better than what I expected. } \\
\text { Most of my expectations from shopping online were confirmed }\end{array}$ \\
\hline $\begin{array}{l}\text { Trust (TRU) } \\
\text { [Gefen, Karahanna, Straub, } \\
\text { 2003; Hassanein, Head, } \\
\text { 2007] }\end{array}$ & $\begin{array}{l}\text { I feel safe in my transactions with the website. } \\
\text { I believe the website can protect my privacy. } \\
\text { I select online stores, which I believe are honest. } \\
\text { I feel that this online vendor would provide me with good service. } \\
\text { I feel that the online vendor is trustworthy }\end{array}$ \\
\hline $\begin{array}{l}\text { Perceived usefulness (PU) } \\
\text { [Davis, 1989; Bigné-Alcañiz } \\
\text { et al., 2008] }\end{array}$ & $\begin{array}{l}\text { Using the Internet enables to finish the shopping tasks more quickly. } \\
\text { Using the Internet for shopping help to make better purchase decisions. } \\
\text { Using the Internet make it easier to make purchases. } \\
\text { Using the Internet for shopping save money. } \\
\text { Find using the Internet for shopping useful }\end{array}$ \\
\hline $\begin{array}{l}\text { Satisfaction (SAT) [Hong, } \\
\text { Thong, Tam, 2006] }\end{array}$ & $\begin{array}{l}\text { I was very satisfied with my overall online shopping experience. } \\
\text { I was very pleased with my overall online shopping experience. } \\
\text { I was very contented with my overall shopping experience. } \\
\text { I was absolutely delighted with my overall shopping experience }\end{array}$ \\
\hline $\begin{array}{l}\text { Perceived enjoyment (ENJ) } \\
\text { [Van der Heijden, 2004; } \\
\text { Hassanein, Head, 2007] }\end{array}$ & $\begin{array}{l}\text { I found my visit to this website interesting. } \\
\text { I found my visit to this website entertaining. } \\
\text { I found my visit to this website enjoyable. } \\
\text { I found my visit to this website pleasant }\end{array}$ \\
\hline
\end{tabular}


Table 6 (end)

\begin{tabular}{l|l}
\hline \multicolumn{1}{c|}{$\mathbf{1}$} & \multicolumn{1}{c}{$\mathbf{2}$} \\
\hline $\begin{array}{l}\text { Past Internet shopping } \\
\text { experiences (PE) [Zeithaml, } \\
\begin{array}{l}\text { Parasuraman, Malhorta, } \\
\text { 2002; Doll et al., 2004; } \\
\text { Khalifa, Liu, 2007] }\end{array}\end{array}$ & $\begin{array}{l}\text { I am relatively satisfied with the Internet shopping experience I have had } \\
\text { on Internet shopping site. } \\
\text { Compared to other Internet shopping sites, I am satisfied with the } \\
\text { shopping experience I have had on this Internet shopping site. } \\
\text { I am relatively satisfied with the product information provided on } \\
\text { Internet shopping site. } \\
\text { I am relatively satisfied with the additional services (order/delivery/ } \\
\text { return) provided on Internet shopping site }\end{array}$ \\
$\begin{array}{l}\text { Intention to repurchase } \\
\text { nline (INT) [Bhattacherjee, } \\
\text { 2001; Devaraj, Fan, Kohli, } \\
\text { 2002] }\end{array}$ & $\begin{array}{l}\text { I intend to continue using online shopping rather than discontinue its use. } \\
\text { Mytention is to continue using online shopping rather than use tradi- } \\
\text { If I could, I would like to continue shopping online as much as possible }\end{array}$ \\
\hline
\end{tabular}

\subsection{Data Collection}

An electronic survey platform was used for data collection, which covered the period between August and October 2014. To conduct the questionnaire, the non-probability sampling was used. In this way, we have asked questions to understand what experiences they have already had and if they were aware to re purchase other products, specifically household products. A questionnaire has been developed initially in English and then translated into French. The targeted population consisted of all people who had bought household equipment at least once through the IKEA website. We have been targeting these specific customers because IKEA is the leader of the household equipment market. IKEA has been maintaining this leadership for the past 9 years. IKEA represents $19.4 \%$ of the market share in France. Two pre-tests were performed prior to data collection to ensure the reliability and validity of the questionnaire. The first pre-test consisted of listening to feedback from 5 potential respondents so as to ensure that the questions were clear and well understood, and where it is necessary to reformulate the questions on the basis of the feedback. The second pre-test was administered to 30 respondents and the data analyzed via SPSS to test the validity and reliability of the questionnaire. In our pre-test sample, we checked the reliability of the constructs. The Cronbach's alpha test on all constructs showed a reliability of over 0.7 (PU: 0.705; PEOU: 0.714; TRU: 0.789; ENJ: 0.857; PE: 0.814; SAT: 0.880; CON: 0.805; INT: 0.756). We could, therefore, proceed with the data collection. In total, 234 respondents answered the questionnaire in final data collection. We then used list-wise deletion, which resulted in a final sample of 218 answers. A test was conducted to compare early and late respondents and to assess the non-response bias [Armstrong, Overton, 1977]. The average values for the first 10 respondents were compared with those of the last 10 respondents. There was no statistical significance difference between the two groups in each case $(p>0.05)$.

Figure 2 contains information regarding demographic characteristics (gender, occupation, income, age) of our total sample.

\section{ANALYSIS}

\subsection{Validity}

Prior to the analysis, we tested the validity of our data. Several academic experts established that the measurement scales were appropriate for measuring the constructs. Furthermore, all measurement scales are widely used in the literature [Babbie, 2001] and more specifically in academic journals 


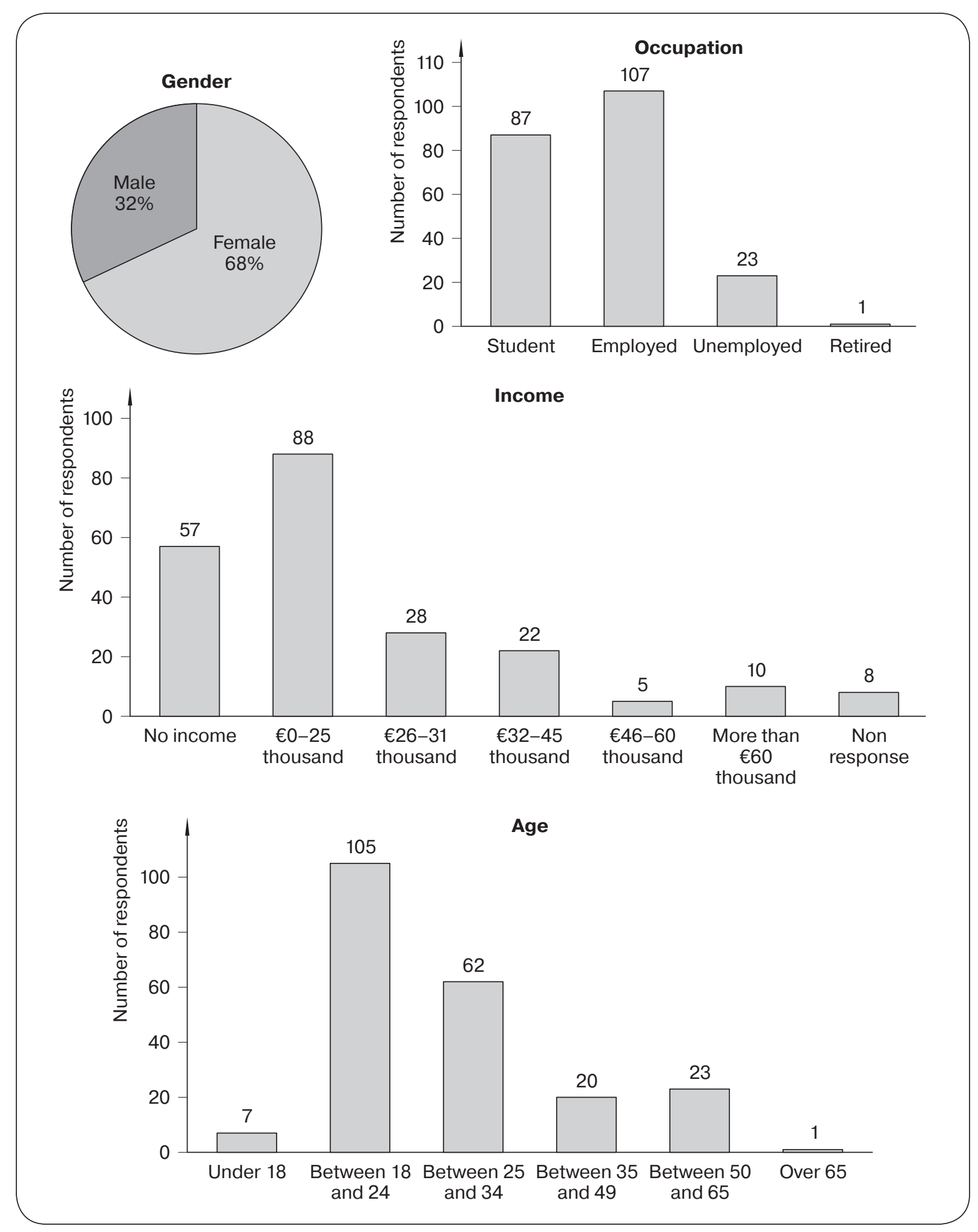

Fig. 2. Demographic characteristics of the sample 
in marketing (MIS Quarterly, Information System Research, Journal of Management Information Systems, Online Information Review, E-service Journal, Human-computer Studies and Journal of the Academy of Marketing Science). The Cronbach's alpha reliability tests [Rust, Cooil, 1994; Zwick, 1988] showed a satisfactory reliability with a coefficient of above 0.70 for all factors (PU: 0.784; PEOU: 0.764; TRU: 0.816; ENJ: 0.887; PE: 0.815; SAT: 0.837; CON: 0.810; INT: 0.772). The results indicate acceptable consistency of the measurement items [Nunnally, 1978].

To assess the convergent validity, we checked that the correlation between items of the same construct was at least 0.3 (PU: 0.525; PEOU: 0.424; TRU: 0.545; ENJ: 0.661; PE: 0.522; SAT: 0.604; CON: 0.479; INT: 0.385). We also checked that the factor loadings were significant and greater than 0.7 .

To assess the discriminant validity, we looked at correlation coefficients between the measures of a construct and measures of conceptually different constructs.

The low to moderate correlations between the items of the constructs indicate discriminant validity.

Finally, to assess the nomological validity, we analyzed two by two correlations within constructs. Since all the signs of the correlations make sense, nomological validity is confirmed.

\subsection{Normality and Multicollinearity}

To assess the normality of our data, we checked that all factors had loadings greater than 0.5. The skew index is below 3 and the kurtosis index is below 10, suggesting that the data is normally distributed. We assessed multicollinearity by calculating bivariate correlations and variance inflation factors. Bivariate correlations did not exceed 0.85 (PU: 0.579; PEOU: 0.677; TRU: 0.649; ENJ: 0.823; PE: 0.560; SAT: 0.686; CON: 0.682; INT: 0.678). Thus, we find no multicollinearity in our dataset.

\subsection{Confirmatory Factor Analysis}

We have been running a confirmation factor analysis (CFA) using AMOS. CFA of measurement model showed a good fit (CMIN/ $d f=1.920, C F I=0.917, I F I=0.918, N F I=$ $=0.844, R M S E A=0.066)$. The results of the measurement model were favorable in that all items loaded significantly on their appropriate factor. All standardized factor loadings were over 0.5 and highly significant $(p<0.001)$, which indicates good convergent validity among the instruments of each construct [Bagozzi, Yi, 1988].

CFA has been performed to assess reliability, convergent validity and discriminant validity of the measurement model.

Cronbach's alpha and composite reliability facilitate the assessment of the construct reliability. Composite Reliabilities $(C R)$ of all constructs are greater than the $\mathbf{0 . 6 0}$ threshold [Bagozzi, Yi, 1988] which ensure the reliability of our constructs. In our data, the $C R$ goes from 0.783 (PEOU) to $0.892(E N J)$ which ensure a good reliability (Table 7).

Table 7

Composite reliability and average variance extracted

\begin{tabular}{l|c|c}
\hline Variable & $\boldsymbol{C R}$ & $\boldsymbol{A V E}$ \\
\hline$I N T$ & 0.792 & 0.568 \\
\hline$P E O U$ & 0.783 & 0.552 \\
\hline$C O N$ & 0.807 & 0.583 \\
\hline$T R U$ & 0.822 & 0.607 \\
\hline$P U$ & 0.785 & 0.549 \\
\hline$S A T$ & 0.839 & 0.637 \\
\hline$E N J$ & 0.892 & 0.735 \\
\hline$P E$ & 0.818 & 0.530 \\
\hline
\end{tabular}

In our study, the standardized loadings are above 0.5 and significant. The results of the measurement model were favorable in that all items loaded significantly on their appropriate factor.

C. Fornell and D. Larcker argued [Fornell, Larcker, 1981] that if the Average Variance Extracted $(A V E)$ is greater than 0.5 of the total variance, convergent validity is estab- 
lished. All items have standardized loadings greater than 0.5 and $A V E$ greater than 0.5 , providing evidence of the measures' convergent validity (Table 7 ).

To assess the discriminant validity, the Fornell-Larcker criterion compares the square root of the constructs' $A V E$ s with the construct correlations [Fornell, Larcker, 1981]. This analysis shows that across all model setups and constructs, each latent variable shares more variance with its own block of indicators than with another latent variable representing a different block of indicators.

Measurement model showed acceptable discriminant validity for all constructs except $P E O U, C O N, S A T$ and $P E$. We decided to maintain the behavioral and emotional dimensions as separate constructs in the measurement model.

\subsection{Structural Equation Modeling}

SPSS and AMOS have been used to perform the statistical analysis of the data.

First, we conducted model specification tests. In our model, which we presented in the literature review, there is one exogenous multi-item latent construct $(P E)$. There are seven multi-item endogenous latent constructs (PEOU, PU, TRU, CON, SAT, PE, $E N J)$. There are 72 regression weights, 40 of which are fixed and 32 of which are estimated. We have 0 covariance and 33 variances, all of which are estimated. In total, there are 105 parameters, 65 of which are to be estimated.

Second, we then performed the model identification. Our model is over-identified: there are 325 distinct sample moments and 65 parameters to be estimated, thereby leaving 260 degrees of freedom. The chi-square value is $492,880(\mathrm{p}<0.001)$.

Third, we then estimate the model. Maximum likelihood estimation can be used since the model is over-identified $(d f=260)$, the observed variables are normally distributed, the latent variables are normally distributed, and we have more than 90 observations.
Fourth, the model evaluation is performed to assess the validity of our measurement model. The overall model fit was good $(C M I N / d f=1.896, C F I=0.915, I F I=$ $=0.916, R M S E A=0.065)$. The $C M I N / d f$ ratio below 3 indicates a favorable model fit [Marsh, Hocevar, 1985]. Consequently, our $C M I N / d f$ is 1.896 , which indicates a good fit. The use of multiple fit indices is recommended [Bagozzi, Yi, 1988]. It is important to consider using incremental fit indices such as CFI and IFI. CFI and IFI of over 0.9 indicate a good model fit [Arbuckle, Wothke, 1995] which is the case in our analysis. Our CFI (0.915) and our IFI (0.916) indicate a good incremental fit. For a good fit, RMSEA of our complex model and for our sample size should be below 0.10 . Our RMSEA is 0.065 , indicating an acceptable model fit.

All standardized factor loadings were over 0.5 and highly significant $(p<0.001)$, which indicates good convergent validity among the instruments of each construct [Bagozzi, Yi, 1988]. The modification indices in the confirmatory factor analysis for omitted paths showed no significant crossloading among the items (i. e. all results are below 0.85). It indicates good discriminant validity [Kline, 1998]. All those results support the overall validity of the constructs measured in this study.

\subsection{Results}

Table 8 presents the estimates and path significance.

Our data support hypotheses 1, 2, and 4 but does not support hypothesis 3. Past internet shopping experience has a highly significant and positive effect on perceived ease of use ( $p<0.001$; estimate: $0.617 ; \mathrm{H} 1)$. Past internet shopping experience has a very significant and very strong impact on confirmation ( $p<0.001$; estimate: 0.736 ; H2) and on online satisfaction $(p<0.001$; estimate: 0.641 ; H4). However, there is no correlation between prior experience and customers' perception of the website (H3). 
Table 8

Results

\begin{tabular}{c|c|c|c|l}
\hline № & Path & Estimate & $\boldsymbol{p}$-value & \multicolumn{1}{|c}{ Hypotheses support } \\
\hline H1 & PE $\rightarrow$ PEOU & 0.617 & 0.000 & Strong support \\
\hline H2 & PE $\rightarrow$ CON & 0.736 & 0.000 & Strong support \\
\hline H3 & PE $\rightarrow$ PU & 0.172 & 0.405 & No support \\
\hline H4 & PE $\rightarrow$ SAT & 0.641 & 0.000 & Strong support \\
\hline H5 & PEOU $\rightarrow$ TRU & 0.943 & 0.000 & Strong support \\
\hline H6 & PEOU $\rightarrow$ ENJ & 0.818 & 0.000 & Strong support \\
\hline H7 & PEOU $\rightarrow$ PU & 0.503 & 0.030 & Support \\
\hline H8 & CON $\rightarrow$ PU & 0.043 & 0.761 & No support \\
\hline H9 & CON $\rightarrow$ SAT & 0.389 & 0.000 & Strong support \\
\hline H10 & TRU $\rightarrow$ PU & 0.053 & 0.581 & No support \\
\hline H11 & TRU $\rightarrow$ INT & -0.052 & 0.375 & No support \\
\hline H12 & ENJ $\rightarrow$ INT & -0.112 & 0.009 & Supported (negative relationship) \\
\hline H13 & PU $\rightarrow$ SAT & 0.067 & 0.324 & No support \\
\hline H14 & PU $\rightarrow$ INT & 0.404 & 0.000 & Strong support \\
\hline H15 & SAT $\rightarrow$ INT & 0.206 & 0.008 & Support \\
\hline
\end{tabular}

The online buyers' perception of a website's ease of use has a significant and positive impact on trust, perceived enjoyment, and perceived usefulness. Our data support hypotheses 5, 6, and 7. The perceived ease of use of a household equipment retail website has a very significant and extremely strong impact on trust ( $p<0.001$; estimate: 0.943 ; H5). The perceived ease of use of household equipment website has a very significant and very strong impact on perceived enjoyment ( $p<0.001$; estimate: 0.818 ; H6). The perceived ease of use of household equipment website has a significant and strong impact on perceived usefulness ( $p<$ $<0.05$; estimate: 0.503; H7).

Expectation-confirmation from users of household equipment retail websites does not influence their perceived usefulness. However, the latter has a significant effect on satisfaction. Our data does not support hypothesis 8 but supports hypothesis 9 . Confirmation of expectations on a product does not have a significant impact on the website's perceived usefulness (H8). However, confirmation has a very significant and positive impact on users' satisfaction with the website $(p<0.001$; estimate: 0.389; H9).

When examining the antecedents of customers' intention to continue purchasing household equipment online, we identified two significant and positive predictors: perceived usefulness and satisfaction; one nonsignificant predictor: trust; and one significant and negative predictor: perceived enjoyment. While H14 and H15 are supported by the analysis, H11 is not and we obtain counterintuitive results concerning H12.

Trust is not a predictor of the website's perceived usefulness (H10). Trust is not a predictor of online repurchase intention either (H11). The perceived usefulness of the website is not a predictor of satisfaction (H13). However, perceived usefulness has a very significant and positive impact on online repurchase intention $(p<0.001$; estimate: $0.404 ; \mathrm{H} 14)$. The website satisfaction has a significant and positive impact on online repurchase intention $(p<0.01$; estimate: $0.206 ; \mathrm{H} 15)$. The perceived enjoyment has a significant and negative impact on the intention to repurchase online $(p<0.01$; estimate: -0.112 ; H12). 


\section{DISCUSSION}

\subsection{Consumers' Past Experience of Online Shopping}

For online buyers, past online shopping experience has strongly significant and positive impact on perceived ease of use, confirmation, and satisfaction, but has no significant effect on perceived usefulness.

Online customers acquire important skills and experience in online buying and will as a result consider online purchasing an easy experience. In other words, familiarity with the website enables the online clients to navigate and find the information they need more easily.

In line with Chen's findings [Chen, 2012] we argue that past internet shopping experience has a significant and strong impact on confirmation and on online satisfaction. Past online shopping experience has a significant and positive impact on users' subsequent experiences, in terms of beliefs and attitude. Future expectations are created based on past internet shopping experience in the household market. Past internet shopping experience has a strong and positive impact on the online purchasing satisfaction. It means that experienced online clients feel more positive about using the website than those who have no online shopping experience.

However, the fact that customers have prior online shopping experiences does not necessarily mean that they will perceive the website to be useful, effective, helpful, functional, or practical more than a person with less experience.

\subsection{Perceived Ease of Use of an Online Household Equipment Retail Store}

Online customers who find the website easy to use will be very likely to trust e-commerce environments in term of privacy, security, absence of errors, protection of personal data, etc. Our data support the argu- ment made by Gefen and Straub [Gefen, Straub, 2003] in this regard.

The perceived ease of use of household equipment website has a very strong impact on perceived enjoyment. The easier it is for a user to navigate an online household equipment store, the greater his/her engagement in online buying. As pointed out in [Kim, Ammeter, 2008], online shopping involves more than the mere acquisition of household equipment such as sofa or table lamp. In this regard, the ability of online customers to find information effectively provides them with a sense of enjoyment.

The perceived ease of use of household equipment website has a strong impact on perceived usefulness. The ability of online clients to find relevant information on household equipment has an impact on their perception of the website's functionality, usefulness. In that sense, clients are more likely to find the IKEA website effective, convenient to use, and helpful if they can easily navigate from page to page.

\subsection{Confirmation}

Expectation-confirmation from users of household equipment retail websites does not influence their perceived usefulness. However, the latter has a significant effect on satisfaction. Bhattacherjee's ECM was validated by several studies [Hong, 2006; Liao, Palvia, Chen, 2009; Wen, Prybutok, $\mathrm{Xu}, 2011$ ], however, was not supported by our data on online household equipment purchase. The perceived usefulness of the IKEA website is not influenced by postpurchase confirmation. It also means that failure to meet the users' expectationsconfirmation does not have an impact on the users' perceived usefulness of the IKEA website. Our data on household appliance online shopping tend to diverge from the results reported by Chen [Chen, 2012], who argued that consumers' confirmation in online purchase has a positive impact on their perception of the website usefulness. 
However, confirmation has a positive impact on users' satisfaction with the website. When online customers' expectations about the household products they have purchased online are confirmed, they tend to be satisfied with the IKEA website. This means that the website played a role in enabling the user to choose the right product and has contributed in reducing the gap between pre- and post- purchase perception.

\subsection{Online Repurchase Intention}

The website's privacy and security practices do not necessarily guarantee that the IKEA website is convenient and functional. This is not in keeping with the argument proposed in [Zhu, Lee, O'Neal, 2011] in this regard. The absence of errors on the website and e-security for customer's personal information does not necessarily encourage online customers to continue purchasing online. The likelihood that an online customer will purchase products from the website again is not significantly predicted by the degree of trust in the household equipment market. Trust appears to be less important for customers of IKEA's online store, probably because there is no need for a high degree of trust when buying a carpet, kitchen furniture or posters. Our findings are similar to the findings of [Wen, Prybutok, Xu, 2011], which do not support the hypothesis of the relationship between trust and online repurchase intention. This empirical study complements earlier studies on trust in e-commerce and online risk [ $\mathrm{Zhu}$, Lee, O'Neal, 2011].

The perceived usefulness of the website is not a predictor of satisfaction. This finding does not support the predictions made by previous research [Devaraj, Fan, Kohli, 2002; Chen, 2012] that perceived usefulness has an impact on e-commerce satisfaction.

IKEA website functionality, the help provided and the practical usefulness has a positive impact on the intention to repurchase online in the future as argued in [Chen, 2012]. Our study supports various models such as the ECM [Bhattacherjee, 2001], Chen's [Chen, 2012] and Wen, Prybutok, Xu's [Wen, Prybutok, Xu, 2011] models.

The website satisfaction has a positive impact on online repurchase intention. When online customers are satisfied, it creates a positive consumption experience encouraging them to return to the website and to repurchase in the future. Our findings are coherent with previous studies [Bhattacherjeein, 2001; Liao, Palvia, Chen, 2009; Hong, 2006; Wen, Prybutok, Xu, 2011]. The IS continuance usage intention is explained by the satisfaction of the website.

Our empirical studies highlight very counter-intuitive findings. The perceived enjoyment has a significant and negative impact on the intention to repurchase online. People who are very involved in the purchasing process are less likely to repurchase online. The less the website is entertaining to procure enjoyment to consumers, the greater the intention to repurchase online. It means that online clients are not on the IKEA website for fun but more for finding useful information they need. Highly counter-intuitive, our data suggest opposite findings to the previous studies (e.g. [Wen, Prybutok, Xu, 2011]) that argued that shopping enjoyment has a positive impact on online users' intention to return. Our empirical study of the household equipment appears to be different from other markets.

\section{CONCLUSION}

In the household equipment market, past internet shopping experience is very important to online buyers by affecting their perceived ease of use, their confirmation and satisfaction. The ease of using a website itself influences the degree of trust, the perceived enjoyment and the perceived usefulness. Online customers' confirmation influences their satisfaction but not the perceived usefulness of the website. The perceived usefulness and satisfaction posi-

PЖM 17 (4): 569-590 (2019) 
tively affect the online repurchase intention of household equipment, while the perceived enjoyment negatively affects the IS continuance usage intention, which is a counter-intuitive finding.

Our findings contribute to the body of literature dealing with consumers' online purchase and repurchase behavior. Our study has been able to encompass the existing works conducted by [Oliver, 1980; Davis, 1989; Wen, Prybutok, Xu, 2011; Chen, 2012]. In particular, our study has been to make those existing work converge into a single model. Bringing together four models into a single model contribute to strengthening the existing body of literature, by confirming existing hypothesis, by not supporting certain hypothesis, and more importantly, by bringing counter intuitive findings. Those counter intuitive findings are opening new avenue for further investigation. In addition, our study offers an empirical contribution by investigating the household equipment market, which differ from existing studies conducted in different empirical settings.

Some limitations existed in our work. First of all, the respondents represented a part of the population and we have seen almost half of respondents had less than 24 years so we cannot generalize the behav-

\section{REFERENCES}

Arbuckle J.L., Wothke W. 1995. Amos 4.0 User's Guide. Small Waters Corporation: Chicago.

Armstrong J.S., Overton T.S. 1977. Estimating nonresponse bias in mail surveys. Journal of Marketing Research 14: 396402.

Babbie E. 2001. Practice of Social Research (9th ed.). Wadsworth Thomson Learning: Belmont, CA.

Bagozzi R., Yi Y. 1988. On the evaluation of structural equation models. Journal of the Academy of Marketing Science 16 (1): 74-94. ior of our respondents to the all online shopping population. Most of our respondents were French people, and for further research it will be interesting to compare people from different cultural backgrounds who may probably have different shopping intentions because it probably impacts their intentions too. In addition, the study has been taking IKEA as an example, meaning that we cannot generalize our findings to other brands.

For further research, it would be interesting to focus more on the relationship between the purchasing enjoyment and the intention to repurchase online in different online markets. While C. Wen, V. Prybutok and $\mathrm{C} . \mathrm{Xu}$ argued that shopping enjoyment has a positive impact on online users' intention to return [Wen, Prybutok, $\mathrm{Xu}$, 2011], we argue that online enjoyment has a negative impact on the online repurchase intention of household equipment. We urge scholars to conduct further empirical studies to further discuss the impact of online shopping enjoyment on the repurchase intention in different markets. In addition, we are suggesting further research to investigate online repurchase intention, using qualitative methods to capture the in depth motivations of customers and to identify new drivers that may explain their behaviors.

Bandura A. 1986. Social Foundations of Thought and Action: A Social Cognitive Theory. Prentice-Hall: Upper Saddle River, NJ.

Bart Y., Shankar V., Sultan F., Urban G.L. 2005. Are the drivers and role of online trust the same for all web sites and consumers? A large-scale exploratory empirical study. Journal of Marketing 69 (4): 133-152.

Bigné-Alcañiz E., Ruiz-Mafé C., Aldás-Manzano J., Sanz-Blas S. 2008. Influence of online shopping information dependency and innovativeness on internet shopping 
adoption. Online Information Review 32 (5): 648-667.

Bhattacherjee A. 2001. Understanding information systems continuance: An expectation-confirmation model. MIS Quarterly 25 (3): 351-370.

Ciornea R. 2013. Drivers of consumer's satisfaction with luxury fashion products and overall satisfaction's impact on repurchase intention. Proceeding of International Conference Marketing - From Information to Decision 6: 51-67.

Chau Y.K.P. 2001. Influence of computer attitude and self-efficacy on IT usage behavior. Journal of End User Computing 13 (1): 26-33.

Chen Y.-Y. 2012. Why do consumers go internet shopping again? Understanding the antecedents of repurchase intention. Journal of Organizational Computing and Electronic Commerce 22 (1): 38-63.

Davis F.D. 1989. Perceived usefulness, perceived ease of use and user acceptance of information technology. MIS Quaterly 13 (3): 319-340.

Davis F. D., Bagozzi R. P., Warshaw P.R. 1989. User Acceptance of Computer Technology: A Comparison of Two Theoretical Models. Management Science 35 (8): 9821003.

Dess G.G., Robinson R.B. 1984. Measuring organizational performance in the absence of objective measures: The case of the privately held firm and conglomerate business unit. Strategic Management Journal 5 (3): 265-273.

Devaraj S., Fan M., Kohli R. 2002. Antecedents of B2C channel satisfaction and preference: Validating e-commerce metrics. Information Systems Research 13 (3): 316333.

Doll W.J., Deng X., Raghunathan T., Torkzadeh G., Xia W. 2004. The meaning and measurement of user satisfaction: A multigroup invariance analysis of the end-user computing satisfaction instrument. Journal of Management Information Systems 21 (1): 227-262.
Fornell C., Larcker D. F. 1981. Evaluating structural equation models with unobservable variables and measurement error. Journal of Marketing Research 18 (1): 39-50.

Gefen D., Karahanna E., Straub W.D. 2003. Trust and TAM in online shopping: An integrated model. MIS Quarterly 27 (1): 51-90.

Gefen D., Straub D. 2003. Managing user trust in B2C e-services. E-service Journal 2 (2): $7-24$.

Hassanein K., Head M. 2007. Manipulating perceived social presence through the web interface and its impact on attitude towards online shopping. Human-Computer Studies 65 (8): 689-708.

Hong S.J., Thong J.Y.L., Tam K.Y. 2006. Understanding continued information technology usage behavior: A comparison of three models in the context of mobile internet. Decision Support Systems 42 (3): 1819-1834.

Karahanna E., Straub D.W., Chervany N.L. 1999. Information technology adoption across time: A cross-sectional comparison of pre-adoption and post-adoption beliefs. MIS Quarterly 23 (2): 183-213.

Kline R.B. 1998. Principles and Practice of Structural Equation Modeling. The Guilford Press: N.Y.

Khalifa M., Liu M. 2007. Online consumer retention: Contingent effects of online shopping habit and online shopping experience. European Journal of Information Systems 16 (6): 780-792.

Kim D.J., Ferrin D.L., Rao H.R. 2008. A trustbased consumer decision-making model in electronic commerce: The role of trust, perceived risk, and their antecedents. Decision Support Systems 44 (2): 544-564.

Kim C., Galliers R.D., Shin N., Ryoo J.-H., Kim J. 2012. Factors influencing internet shopping value and customer repurchase intention. Electronic Commerce Research and Applications 11 (4): 374-387.

Kim D., Ammeter A. P. 2008. Examining shifts in online purchasing behavior: De- 
coding the "net generation". Proceedings of the Academy of Information and Management Sciences 12 (1): 7-12.

Kim M., Lee C.-K., Chung N., Kim W.G. 2014. Factors affecting online tourism group buying and the moderating role of loyalty. Journal of Travel Research 53 (3): 380-394.

Korzaan M.L., Rutner P.S. 2013. Investigating the role of psychological factors in explaining online behavior. Feature Edition 3: 69-94.

Kuan H.H., Bock G. W., Vatthanophas V. 2008. Comparing the effects of website quality on customer initial purchase and continued purchase at e-commerce websites. $B e$ haviour \& Information Technology 27 (1): 3-16.

Lee Z.C., Hodges N. 2012. An investigation of antecedents and consequences of consumers attitudes toward an apparel website. Global Conference on Business \& Finance Proceedings 7 (1): 718-734.

Liao C., Palvia P., Chen J.-L. 2009. Information technology adoption behavior life cycle: Toward a technology continuance theory (TCT). International Journal of Information Management 29 (4): 309320.

Locke E.A. 1976. The nature and causes of job satisfaction. Handbook of Industrial and Organizational Psychology 1: 12971343.

Marsh H. W., Hocevar D. 1985. Application of confirmatory factor analysis to the study of self-concept: First- and higher-order factor models and their invariance across groups. Psychological Bulletin 97 (3): 562582.

Nunnally J. 1978. Psychometric Theory. McGraw-Hill: N.Y.

Oliver R.L. 1980. A cognitive model of the antecedents and consequences of satisfactions decisions. Journal of Marketing Research 17 (4): 460-469.
Ormrod J.E. 1999. Human Learning (3rd ed.). Prentice-Hall: Upper Saddle River, NJ.

Radner R., Rothschild B. 1975. On the allocation of effort. Journal of Economic Theory 10 (3): 358-376.

Rice M. 1997. What makes users revisit a web site? Marketing News 31 (6): 12-13.

Rust R.T., Cooil B. 1994. Reliability measures for qualitative data: Theory and implications. Journal of Marketing Research 31 (1): 1-14.

Tong X. 2010. A cross-national investigation of an extended technology acceptance model in the online shopping context. International Journal of Retail \& Distribution Management 38 (10): 742-759.

Van der Heijden H. 2004. User acceptance of hedonic information systems. MIS Quarterly 28 (4): 695-704.

Wen C., Prybutok V.R., Xu C. 2011. An integrated model for consumer online repurchase intention. Journal of Computer Information Systems 52 (1): 14-23.

Zeithaml V.A., Parasuraman A., Malhorta A. 2002. A service quality delivery through web sites: A critical review of extant knowledge. Journal of the Academy of Marketing Science 30 (4): 362-375.

Zhang Y., Fang Y., Wei K.-K., Ramsey E., McCole P., Chen H. 2011. Repurchase intention in $\mathrm{B} 2 \mathrm{C}$ commerce - a relationship quality perspective. Information \& Management 48 (6): 192-200.

Zhu D.S., Lee Z.C.R., O'Neal G.S. 2011. Mr.Risk! Please trust me: Trust antecedents that increase online consumer purchase intention. Journal of Internet Banking and Commerce 16 (3): 1-23.

Zumpe S., Van der Heijden H. 2007. On the use of variable user goals to measure perceived usefulness. ECIS 2007 Proceedings 68: 1334-1343.

Zwick R. 1988. Another look at interrater agreement. Psychological Bulletin 103 (3): 374-378.

Initial Submission: September 30, 2019 Final Version Accepted: December 27, 2019 
Налерение совершения повторных онлайн-покупок: элпирическое исследование рынка бытового оборудования

\section{Ж. Видлен, Л. Скарингелла}

Реннская школа бизнеса, Франция

Развитие электронной коммерции способствовало резкому увеличению объема онлайн-покупок. В статье разрабатывается теоретическая модель на основе концепций принятия технологий, ожидания-подкрепления и продолжительности информационных систем. Впервые проводится эмпирическое исследование намерения совершения повторных онлайн-покупок на рынке бытового оборудования. Анализ выполнен на материале опроса 218 клиентов IKEA при помощи метода моделирования структурных уравнений. Можно сделать ряд выводов. Во-первых, прошлый опыт интернет-покупок (past Internet shopping expereience) влияет на простоту пользования (perceived ease of use) онлайн-сервисом, подтверждение ожиданий (confirmation) и удовлетворенность (satisfaction) клиентов. Во-вторых, удобство использования веб-сайта положительно взаимосвязано с доверием к ресурсу (trust), воспринимаемым удовольствием (perceived enjoyment) и полезностью использования. В-третьих, установлено, что подтверждение ожиданий воздействует на удовлетворенность, но не оказывает эффекта на воспринимаемую полезность использования (perceived usefulness). B-четвертых, на намерение совершения повторных онлайн-покупок влияют воспринимаемая полезность и удовлетворенность. В-пятых, воспринимаемое удовольствие негативно взаимосвязано с намерением повторных онлайн-покупок. Вклад исследования заключается в интеграции ранее разработанных моделей намерений совершения повторных онлайн-покупок.

Ключевые слова: Интернет, электронная коммерция, повторная покупка, бытовое оборудование, онлайн-покупка, IKEA.

JEL: M31.

For citation: Videlaine G., Scaringella L. 2019. Online repurchase intention: Empirical study on the household equipment market. Russian Management Journal 17 (4): 569-590.

Статья поступила в редакцию 30 сентября 2019 г. Принята к публикаиии 27 декабря 2019 г. 